\title{
PENGARUH PARTISPASI ANGGARAN, KOMITMEN ORGANISASI TERHADAP SENJANGAN ANGGARAN DENGAN LOCUS OF CONTROL SEBAGAI VARIABEL MODERASI
}

\author{
Farid Madjodjo \\ Pascasarjana Universitas Muslim Indonesia \\ Jln. Urip Sumoharjo Km. 5 Makassar \\ Madj.farid@gmail.com
}

\begin{abstract}
Abstrak: Penelitian ini bertujuan untuk menguji, 1) pengaruh partisipasi anggaran terhadap senjangan anggaran, 2) pengaruh komitmen organisasi terhadap senjangan anggaran, 3) pengaruh partisipasi anggaran terhadap senjangan anggaran yang di moderasi oleh locus of control, 4) pengaruh komitmen organisasi terhadap senjangan anggaran yang di moderasi oleh locus of control. Penelitian ini merupakan penelitian kuantitatif yang menggunakan pendekatan kausal dengan jenis data yang digunakan adalah data primer yang diperoleh dari hasil penyebaran kuesioner dan di ukur menggunakan skala likert lima point. Populasi penelitian ini adalah 28 SKPD di Pemerintah Kota Tidore Kepulauan Provinsi Maluku Utara dengan jumlah responden sebanyak 90 . Teknik pengambilan sampel menggunakan purposive sampling. Metode analisis yang digunakan adalah Moderated Regression Analysis (MRA) dengan bantuan Statistical Package for Social Science (SPSS).

Hasil penelitian menunjukkan bahwa 1) partisipasi anggaran berpengaruh positif dan signifikan terhadap senjangan anggaran, 2) komitmen organisasi berpengaruh negatif dan signifikan terhadap senjangan anggaran, 3) partisipasi anggaran berpengaruh negatif tidak signifikan terhadap senjangan anggaran yang di moderasi oleh locus of control, 4) komitmen organisasi berpengaruh positif dan signifikan terhadap senjangan anggaran yang di moderasi oleh locus of control.
\end{abstract}

Kata kunci: Senjangan Anggaran, Partisipasi Anggaran, Komitmen Organisasi, Locus Of Control. 


\section{PENDAHULUAN}

Tujuan utama dari organisasi sektor publik adalah memberikan pelayanan kepada masyarakat, sehingga cita-cita dari pemerintah tersebut sejalan dengan keinginan masyarakat (Nordiawan, 2010). Dalam sektor publik anggaran harus diinformasikan kepada publik untuk dikritik, didiskusikan, dan diberi masukan (Mardiasmo, 2002). Untuk itu dalam proses penyusunan anggaran perlu dihindari dari hal-hal yang dapat mengurangi manfaat seperti senjangan anggaran.

Menurut Anthony dan Govindarajan (2007), senjangan anggaran (budgetary slack) adalah perbedaan antara anggaran yang dilaporkan dengan anggaran yang sesuai dengan estimasi terbaik bagi organisasi. Estimasi yang dimaksud adalah anggaran yang sesungguhnya terjadi dan sesuai dengan kemampuan terbaik perusahaan. Kesenjangan anggaran atau slack anggaran menurut Ikhsan dan Ishak (2005) Selisih anggaran yang bersifat menguntungkan dalam laporan realisasi anggaran kemungkinan dipicu salah satunya oleh adanya kesenjangan anggaran.

Laporan Anggaran Pendapatan dan Belanja Daerah (APBD) tahun anggaran 2015 kota Tidore Kepulauan. Anggaran pendapatan daerah sebesar Rp. 713.691.092.882 dan realisasinya sebesar Rp. 710.047.171.369 atau 99,49\%, sedangkan anggaran belanja sebesar Rp. 745.101.277.060 dan realisasinya sebesar Rp. 702.183.492.814 atau 94,24\%. Dari data tersebut, peneliti menduga bahwa terjadinya senjangan anggaran pada pemerintah daerah kota Tidore Kepulauan. http://www.abadikini.com/read/20160701/walikota-tidore-kepulauansampaikan-lpp-apbd-tahun-anggaran-2015.

Partisipasi anggaran merupakan pendekatan yang secara umum dapat meningkatkan prestasi (kinerja) yang pada akhirnya dapat meningkatkan efektivitas suatu organisasi. Adapun partisipasi mendorong setiap manajer untuk meningkatkan prestasinya dan bekerja lebih keras dan menganggap bahwa target organisasi merupakan target pribadinya (Bambang, 2002).

Komitmen organisasi menunjukkan tingkat keterikatan individu kepada organisasi yang dicerminkan dengan adanya keyakinan dan ingin mempertahankan keikutsertaan dalam organisasi tersebut (Soejoso, 2004).

Locus Of Control adalah salah satu karakteristik kepribadian yang terdapat dalam diri tiap-tiap orang yang mempengaruhi bagaimana individu tersebut mengartikan atau mempresepsikan peristiwa yang dihadapinya.

Berdasarkan penelitian sebelumnya terdapat ketidakkonsistenan antara peneliti satu dengan yang lainnya. Seperti penelitian yang dilakukan oleh Erina dan Suartana (2016), Faujiyah (2007), Lestari dan Dwija (2015) dan Kartika (2007) menyatakan bahwa partisipasi anggaran dan kesenjangan anggaran mempunyai hubungan yang positif, yaitu semakin tinggi tingkat partisipasi anggaran maka potensi terjadinya senjangan anggaran semakin tinggi. Sedangkan penelitian yang 
dilakukan oleh Priliandani dan Putra (2016), Sosiawan (2014), dan Ramadani (2013), menunjukkan partisipasi anggaran dan kesenjangan anggaran mempunyai hubungan yang negatif. Hasil penelitian yang berlawanan ini mungkin karena ada faktor lain yang juga berpengaruh terhadap hubungan antara partisipasi anggaran dan kesenjangan anggaran. Govindarajan (1986) dalam Falikhatun (2007) menyatakan bahwa perbedaan hasil penelitian tersebut dapat diselesaikan melalui pendekatan kontinjensi (contingency approach). Hal ini dilakukan dengan memasukkan variabel lain yang mungkin mempengaruhi partisipasi anggaran, komitmen dengan senjangan anggaran (budgetary slack).

Pendekatan kontijensi yang digunakan dalam penelitian ini yaitu Locus Of Control yang dinyatakan sebagai variabel moderasi. Penggunaan locus of control sebagai variabel moderasi yaitu untuk mengetahui hubungan antara partisipasi anggaran, komitmen organisasi terhadap senjangan anggaran yang dilihat dari karakteristik kepribadian yang ada pada bawahan yang berpartisipasi dalam proses penyusunan anggaran maupun karakteristik kepribadian bawahan dalam suatu organisasi, tinggi rendahnya komitmen organisasi tergantung pada locus of control yang dimikili oleh bawahan tersebut.

Perbedaan penelitian ini dengan penelitian terdahulu yaitu, penelitian ini untuk mengetahui pengaruh kinerja individu dan karakteristik personal yang berpartisipasi pada penyusunan anggaran sehubungan dengan sistem anggaran berbasis kinerja, dengan menggunakan variabel locus of control serta menguji peran organisasi yang dilihat dari karakteristik personal dengan menggunakan variabel komitmen organisasi, sedangkan pada penelitian sebelumnya lebih banyak hanya fokus untuk menguji pengaruh peran organisasi dalam proses partisipasi penyusunan anggaran pada budgetary slack, dengan menggunakan variabel komitmen organisasi, budaya organisasi dan ketidakpastian lingkungan.

\section{TINJAUAN PUSTAKA}

\section{Agency Theory}

Penjelasan konsep senjangan dapat dimulai dari pendekatan agency theory. Praktik senjangan anggaran dalam prespektif agency theory dipengaruhi oleh adanya konflik kepentingan antara agent dengan principal yang timbul ketika setiap pihak untuk mencapai atau mempertahankan tingkat kemakmuran yang dikehendakinya. Agency theory menjelaskan fenomena yang terjadi apabila atasan mendelegasikan wewenangnya kepada bawahan untuk melakukan suatu tugas atau otoritas untuk membuat keputusan, Anthony dan Govindarajan, 1998 dalam Latuheru, 2005. 


\section{Teori Kontijensi}

Teori kontijensi menjelaskan bahwa desain dan sistem pengendalian bergantung pada konteks organisasi dimana pengendalian tersebut dilakukan. Pendekatan kontijensi merupakan sebuah aplikasi konsep yang menyatakan bahwa tidak ada suatu sistem kontrol terbaik yang dapat diterapkan untuk semua organisasi dan penerapan sistem yang tepat harus memandang adanya keterlibatan variabel kontekstual dimana organisasi tersebut berada.

\section{Senjangan Anggaran}

Falikhatun (2007) mengemukakan, senjangan anggaran terjadi jika keterlibatan bawahan dalam penyusunan anggaran tersebut disalahgunakan. Hal ini terjadi ketika bawahan melaporkan informasi yang bias demi kepentingan pribadinya. Dewi (2008) menyatakan ada tiga indikator dalam senjangan anggaran yaitu :

1. Perbedaan jumlah dengan estimasi terbaik

2. Target anggaran

3. Kondisi lingkungan

\section{Partisipasi Anggaran}

Partisipasi adalah suatu proses pengambilan keputusan bersama oleh dua atau lebih yang mempunyai dampak masa depan bagi pihak yang membuat keputusan tersebut, Mulyadi (2001). Partisipasi pimpinan dalam proses penyusunan anggaran merupakan proses dimana pimpinan dinilai kinerjanya, serta keterlibatan pimpinan dalam mengkoordinasikan anggotanya. Hansen dan Mowen (2009) ada tiga masalah yang timbul yang menjadi kelemahan partisipasi anggaran antara lain :

1. Menetapkan standar yang terlalu tinggi terlalu rendah

2. Membuat kelonggaran dalam anggaran

3. Partisipasi semu (pseudoparticipation)

\section{Komitmen Organisasi}

Robbins dan Judge (2007) menyatakan bahwa komitmen organisasi (organization Commitment) merupakan suatu keadaan dimana seorang karyawan memihak terhadap tujuan-tujuan organisasi serta memiliki keinginan untuk mempertahankan keanggotaannya dalam organisasi tersebut. Cook dan Wall (1980) dalam Latuheru (2006) adalah :

1) Loyalitas pada organisasi

2) Hasrat untuk bertahan menjadi bagian dari organisasi

3) Keinginan untuk bekerja keras

4) Affective commitment

5) Loyalitas dalam bekerja

\section{Locus Of Control}

Hapsari (2010) menyatakan bahwa locus of control ialah keyakinan yang dimiliki oleh setiap individu dalam mengendalikan setiap kejadian yang dialaminya. Locus of 
control dapat dilihat dari dua dimensi yang berbeda yakni locus of control internal dan locus of control eksternal. Rotler dalam Robbins (1998) terdapat tiga indikator utama dalam locus of control yaitu :

1. Kepercayaan akan adanya takdir

2. Kepercayaan diri

3. Usaha atau kerja keras

\section{KERANGKA KONSEPTUAL DAN HIPOTESIS PENELITIAN}

\section{Kerangka Konseptual}

Pembentukan kerangka konseptual bertujuan untuk menjawab dan memecahkan masalah penelitian, yaitu penyusunan hipotesis yang merupakan dugaan sementara peneliti. Kerangka konseptual dalam penelitian ini dapat dilihat pada gambar dibawah ini.

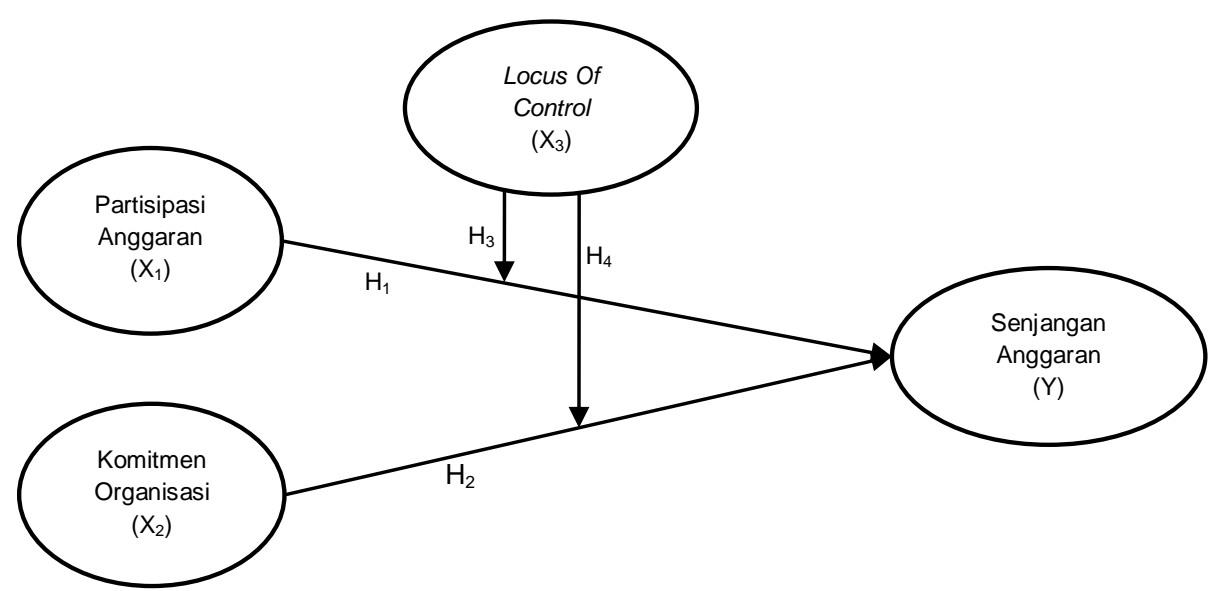

\section{Hipotesis Penelitian}

1. Pengaruh Partisipasi Anggaran terhadap Senjangan Anggaran

Partisipasi yang tinggi dalam proses pembuatan anggaran akan memberikan kesempatan lebih besar kepada bawahan untuk melakukan senjangan dan sebaliknya ketika partisipasi rendah harapan melakukan senjangan anggaran semakin rendah (Erni, 2014). Kartika (2010) menyatakan bahwa tinggi partisipasi penyusunan anggaran membuat karyawan atau bawahan mengecilkan kapabilitas produktifnya, hal ini menyebabkan terjadinya suatu senjangan anggaran yang semakin besar antara bawahan dan atasan. Berdasarkan uraian diatas, maka dapat dihipotesiskan:

$\mathrm{H}_{1}$ : Partisipasi anggaran berpengaruh positif terhadap senjangan anggaran.

2. Pengaruh komitmen organisasi terhadap senjangan anggaran

Komitmen organisasi menunjukkan tingkat keterikatan individu kepada organisasi yang dicermintan dengan adanya keyakinan dan ingin mempertahankan keikutsertaan dalam organisasi tersebut, Soejoso (2004). 
Berkaitan dengan penelitian mengenai komitmen organisasi, penelitian Darlis (2002) menunjukkan bahwa semakin besar komitmen organsasi akan menurunkan keinginan individu yang ikut berpartisipasi dalam penyusunan anggaran dalam melakukan senjangan anggaran. Berdasarkan uraian diatas, maka dapat dihipotesiskan:

$\mathrm{H}_{2}$ : Komitmen organisasi berpengaruh negatif terhadap senjangan anggaran.

3. Pengaruh partisipasi anggaran terhadap senjangan anggaran yang dimoderasi oleh locus of control

Pengaruh partisipasi anggaran terhadap senjangan anggaran diperkuat dan diperlemah oleh locus of control. Bila manager berpandangan bahwa faktor penentu tersebut berada dalam kendali individu (internal locus of control), maka manajer akan berusaha secara optimal untuk mempengaruhi organisasi agar dapat mencapai target yang ditentukan.

Hasil penelitian yang dilakukan Erawati (2016) tentang Pengaruh Partisipasi Anggaran Terhadap Kinerja dan Budgetary Slack dengan locus of control sebagai variabel pemoderasi mendukung hasil penelitian Sinaga (2013), yang menggambarkan bahwa locus of control internal memperkuat hubungan antara partisipasi anggaran dengan senjangan anggaran. Berdasakan uraian diatas, maka dapat dihipotesiskan:

$\mathrm{H}_{3}$ : Partisipasi anggaran berpengaruh negatif terhadap senjangan anggaran yang dimoderasi oleh locus of control.

4. Komitmen organisasi berpengaruh terhadap senjangan anggaran yang dimoderasi oleh locus of control.

Komitmen organisasi yang tinggi akan mengurangi keinginan individu untuk melakukan senjangan anggaran. sebaliknya bila komitmen organisasi rendah, maka kepentingan pribadinya lebih diutamakan, dan dapat melakukan senjangan anggaran agar anggaran mudah dicapai dan pada akhirnya nanti keberhasilan sasaran anggaran tersebut dapat mempertinggi penilaian kinerjanya karena berhasil dalam pencapaian tujuan. Locus of control dapat diartikan sebagai cara pandang seseorang terhadap suatu peristiwa apakah dia dapat atau tidak dapat mengendalikan (kontrol) peristiwa yang terjadi padanya. Jika individu dengan komitmen organisasi tinggi kemudian didukung dengan locus of control internal yang baik maka senjangan anggaran tidak akan terjadi. Berdasarkan uraian, maka dihipotesiskan:

$\mathrm{H}_{4}$ : Komitmen organisasi berpengaruh negatif terhadap senjangan anggaran yang dimoderasi oleh locus of control 


\section{METODE PENELITIAN}

\section{Populasi dan Teknik Sampel}

Populasi pada penelitian ini adalah Satuan Kerja Perangkat Daerah (SKPD) Kota Tidore kepulauan, yaitu sebanyak 28 SKPD. Teknik Pengambilan sampel pada penelitian ini adalah dengan cara pusposive sampling, merupakan suatu teknik penentuan sampel dengan kriteria tertentu.

\section{Metode Pengumpulan Data}

Metode pengumpulan data yang digunakan pada penelitian ini adalah melalui survey berupa penyebaran kuesioner. Kuesioner disertai surat permohonan untuk menjadi responden diberikan kepada responden. Jika ada halangan tertentu, responden diberikan kebijakan berdasarkan kesepakatan antara peneliti dengan responden.

\section{Metode Analisis Data}

\section{Uji Instrumen}

a. Uji Varliditas (test of validity)

Uji validitas berguna untuk menentukan seberapa cermat suatu alat melakukan fungsi ukurannya, jika $r_{\text {hitung }}>r_{\text {tabel }}$ maka item tersebut dinyatakan valid dan dapat digunakan dalam analisis selanjutnya.

b. Uji Reliabilitas (test of reliability)

Kriteria penilaan uji reliabilitas menurut Ghozali (2006) adalah: Suatu konstruk atau variabel dinyatakan reliabel jika memberikan nilai Cronbach Alpha $>0,6$.

\section{Uji Asumsi Klasik}

a. Uji Normalitas Residual

Uji normalitas dilakukan dengan metode kolmogorov sminov dengan melihat nilai signifikansi pada 0,05 . Jika nilai signifikansi yang dihasilkan $\geq 0,05$ maka data berdistribusi normal.

b. Uji Multikolinieritas

Untuk menguji adanya multikolinieritas dapat dilihat melalui nilai variance inflantion factor (VIF) dan tolerance. Jika VIF $<10$ dan tolerance $>0,1$ maka tidak terjadi multikolinieritas.

c. Uji Heteroskedastisitas

Dalam uji ini, apabila hasil sig > 0,05 maka tidak terdapat gejala heterokedastisitas, model yang baik adalah tidak terjadi heterokedastisitas.

\section{Analisis Regresi Berganda}

Model analisis data dan uji hipotesis dalam penelitian ini adalah model analisis regresi moderasi interaksi (Moderated Regression Analysis). Analisis regresi ini merupakan aplikasi khusus regresi linier berganda yang mana dalam persamaan regresinya mengandung unsur interaksi (perkalian dua atau lebih variabel independen). Secara sistematis diperoleh persamaan regresi:

$$
Y=a+\beta_{1} X_{1}+\beta_{2} X_{2}+\beta_{3} X_{1} X_{3}+\beta_{4} X_{2} X_{3}+e
$$


Keterangan :

$$
\begin{array}{ll}
\mathrm{Y} & =\text { Senjangan Anggaran (SA) } \\
\mathrm{a} & =\text { Konstantas } \\
\beta_{1}, \beta_{2}, \beta_{3}, \beta_{4} & =\text { Koefisien Regresi } \\
\mathrm{X}_{1} & =\text { Partisipasi Anggaran (PA) } \\
\mathrm{X}_{2} & =\text { Komitmen Organisasi (KO) } \\
\mathrm{X}_{3} & =\text { Locus Of Control (LOC) } \\
\mathrm{X}_{1}{ }^{*} \mathrm{X}_{3} & =\text { Interaksi Partisipasi Anggaran dengan Locus of Control } \\
\mathrm{X}_{2}{ }^{*} \mathrm{X}_{3} & =\text { Interaksi Komitmen Oragnisasi dengan Locus of Control } \\
\mathrm{e} & =\text { Standar Error }
\end{array}
$$

a. Koefisien determinasi

Koefisien determinasi merupakan besarnya kontribusi variabel bebas terhadap variabel terikatnya. Semakin tinggi koefisien determinasi, semakin tinggi kemampuan variabel bebas dalam menjelaskan variasi perubahan pada variabel terikatnya (Suliyanto, 2011:55).

b. Uji kelayakan model $\mathrm{F}$ (F-test)

Uji $F$ pada dasarnya menunjukkan apakah semua variabel bebas dalam model berpengaruh secara besama-sama terhadap varibel terikat. Dengan ketentuan bahwa jika $p$ value $<(\alpha)=0,05$ dan $f_{\text {hitung }}>f_{\text {tabel }}$, berarti model tersebut signifikan dan bisa digunakan untuk menguji hipotesis. Dasar pengambilan keputusan adalah :

1) Jika $F_{\text {hitung }}>F_{\text {tabel, }}$ maka $\mathrm{H}_{\mathrm{a}}$ diterima dan $\mathrm{H}_{0}$ ditolak

2) Jika $F_{\text {hitung }}<\mathrm{F}_{\text {tabel, }}$ maka $\mathrm{H}_{\mathrm{a}}$ ditolak dan $\mathrm{H}_{0}$ diterima

c. Uji hipotesis (Uji T)

Uji $t$ dilakukan untuk menguji hipotesis atau pengaruh secara parsial (per variabel bebas) terhadap variabel terikat, Apabila tingkat signifikansi $t \leq 0,05$ maka hipotesis yang diajukan dalam penelitian ini diterima (Suliyanto, 2011:67).

\section{Definisi Operasional dan Pengukurannya}

1. Senjangan Anggaran

Senjangan anggaran adalah perbedaan antara jumlah anggaran yang di nyatakan dan estimasi anggaran terbaik yang secara jujur dapat diprediksikan dengan mengestimasikan pendapatan lebih rendah dan biaya lebih tinggi, (Sinaga, 2013). Di ukur menggunakan skala likert 5 point.

2. Partisipasi Anggaran

Partisipasi anggaran merupakan suatu proses pengambilan keputusan bersama oleh dua pihak atau lebih yang mempunyai dampak masa depan bagi pihak yang membuat keputusan tersebut, (Mulyadi, 2001). Di ukur menggunakan skala likert 5 point.

3. Komitmen Organisasi

Komitmen organisasi adalah suatu dorongan dari dalam individu untuk berbuat sesuatu agar dapat menunjang keberhasilan organisasi sesuai dengan tujuan dan lebih mengutamakan kepentingan organisasi, (Wiener, 1982 dalam Latuheru, 2005). Di ukur menggunakan skala likert 5 point. 


\section{Locus of Control}

Locus of control merupakan tingkatan dimana seseorag menerima tanggungjawab personal terhadap apa yang terjadi pada mereka, (Sinaga, 2013). Di ukur menggunakan skala likert 5 point.

\section{HASIL DAN PEMBAHASAN}

\section{Hasil Penelitian}

\section{Pengujian Instrumen Penelitian}

a. Uji Validitas

Berdasarkan hasil pengolahan data didapatkan bahwa nilai Corrected ItemTotal Corrected untuk masing-masing item variabel $\mathrm{X}_{1}, \mathrm{X}_{2}, \mathrm{X}_{3}$ dan $\mathrm{Y}$ semuanya di atas $r_{\text {tabel. }}$. Maka disimpulkan bahwa semua item pernyataan dalam variabel penelitian semuanya valid.

b. Uji Reliabilitas

Berdasarkan pengujian diketahui bahwa masing-masing variabel dalam penelitian memiliki nilai Cronbach's alpha di atas 0,60, dengan demikian semua instrumen yang digunakan dalam penelitian ini reliable.

\section{Uji Asumsi Klasik}

a. Uji Normalitas Residual

Dalam penelitian ini uji normalitas residual menggunakan metode Kolmogorov Sminov untuk mendeteksi terpenuhi atau tidaknya uji normalitas dengan ketentuan bila signifikansi tiap variabel lebih besar atau sama dengan 0,05 maka berdistribusi normal. Berdasarkan hasil pengujian diketahui bahwa nilai probabilitas $\geq 0,05$ yaitu sebesar 0,502 maka dapat disimpulkan bahwa semua data dalam penelitian ini normal. Hasil pengujian dapat di lihat pada tabel di bawah ini :

\section{Tabel Uji Normalitas Residual}

One-Sample Kolmogorov-Smirnov Test

\begin{tabular}{|ll|r|}
\hline & & \multicolumn{2}{|c|}{$\begin{array}{c}\text { Unstandardized } \\
\text { Residual }\end{array}$} \\
\hline N & Mean & 90 \\
Normal Parameters & a,b & Std. Deviation \\
& Absolute & 2.31002919 \\
& Positive & .087 \\
Most Extreme Differences & Negative & .052 \\
& & -.087 \\
Kolmogorov-Smirnov Z & .826 \\
Asymp. Sig. (2-tailed) & .502 \\
\hline a. Test distribution is Normal. & \\
b. Calculated from data. & \\
Sumber : Data Primer Diolah, 2017 &
\end{tabular}

b. Uji Mulitikolinieritas

Dari hasil pengujian diketahui bahwa nilai variance inflantion factor (VIF) untuk masing-masing variabel bebas pada penelitian ini kurang dari 10 dan tolerance berada diatas 0.1 . Sehingga tidak adanya korelasi antara sesama variabel bebas dalam model regresi sehingga tidak terdapat masalah 
multikolinieritas. Hasil pengujian multikolinieritas dapat di lihat pada tabel sebagai berikut :

\section{Tabel Uji Multikolinieritas}

\begin{tabular}{|c|c|c|c|}
\hline & \multicolumn{3}{|c|}{ Coefficients $^{a}$} \\
\hline \multirow{2}{*}{\multicolumn{2}{|c|}{ Model }} & \multicolumn{2}{|c|}{ Collinearity Statistics } \\
\hline & & Tolerance & VIF \\
\hline \multirow{4}{*}{1} & (Constant) & & \\
\hline & $\mathrm{PA}(\mathrm{X} 1)$ & .975 & 1.026 \\
\hline & $\mathrm{KO}(\mathrm{X} 2)$ & .978 & 1.022 \\
\hline & LOC (X3) & .992 & 1.008 \\
\hline
\end{tabular}

c. Uji Heterokedastisitas

Untuk mendeteksi adanya heterokedastisitas diuji dengan menggunakan metode glejser. Pengujian ini membandingkan nilai signifikan dari masingmasing variabel. Jika signifikan diatas 0,05 atau $5 \%$ berarti model regresi tidak mengandung adanya heterokedastisitas. Berdasarkan hasil pengujian diketahui bahwa tingkat signifikan masing-masing variabel pada penelitian ini lebih besar dari $\alpha=0,05$, yang berarti bahwa model yang digunakan dalam penelitian ini baik, karena tidak terjadi heterokedastisitas.

\section{Hasil Statistik Deskriptif}

Hasil pengujian statistik deskriptif dapat dilihat pada di bawah ini :

Descriptive Statistics

\begin{tabular}{|l|r|r|r|r|r|}
\hline & N & Minimum & Maximum & \multicolumn{1}{c|}{ Mean } & Std. Deviation \\
\hline Partisipasi Anggaran & 90 & 16 & 22 & 19.32 & 1.841 \\
Komitmen organisasi & 90 & 18 & 24 & 21.40 & 2.092 \\
Locus Of Control & 90 & 30 & 40 & 35.83 & 2.670 \\
Senjangan Anggaran & 90 & 19 & 29 & 26.21 & 2.524 \\
Valid N (listwise) & 90 & & & & \\
\hline
\end{tabular}

Sumber : Data Primer Diolah, 2017

Berdasarkan tabel di atas dapat diketahui bahwa jumlah responden (N) dari penelitian ini adalah sebanyak 90 . Nilai terendah dari data ditunjukkan oleh skor minimum dalam tabel, sedangkan nilai tertinggi dari data ditunjukkan oleh skor maksimum. Mean digunakan untuk mengukur nilai rata-rata dari data, standard deviation menunjukkan simpanan baku. Variabel partisipasi anggaran $\left(\mathrm{X}_{1}\right)$ mempunyai skor minimum 16, dan skor maksimum 22, sehingga diperoleh skor rata-rata sebesar 19,32, dan standard deviation sebesar 1,841. Variabel komitmen organisasi $\left(\mathrm{X}_{2}\right)$ mempunyai skor minimum 18, skor maksimum 24 , sehingga diperoleh skor rata-rata sebear 21,40, dan standard deviation sebesar 2,092. Variabel locus of control mempunyai skor minimum 30, skor maksimum 40, sehingga diperoleh skor rata-rata 35,83, dan standard deviation sebesar 2,670. Variabel senjangan anggaran ( $Y$ ) mempunyai skor minimum 19, skor maksimum 29, sehingga diperoleh skor rata-rata sebesar 26,21, dan standard deviation sebesar 2,524. 


\section{Moderated Regression Analysis (MRA) dan Pengujian Hipotesis}

Analisis regresi berganda dilakukan dengan membandingkan thitung dengan $t_{\text {tabel }}$ dan nilai signifikan dengan a (alpha) yang diajukan yaitu $95 \%$ atau $\alpha=0,05$. Secara rinci hasil pengujian regresi berganda dapat dilihat pada tabel di bawah ini :

\section{Tabel Uji Moderated Regression Analysis (MRA)}

\begin{tabular}{|l|r|r|r|r|r|}
\hline \multicolumn{7}{|c|}{ Coefficients $^{\mathrm{a}}$} \\
& \multicolumn{2}{|c|}{ Unstandardized Coefficients } & $\begin{array}{c}\text { Standardized } \\
\text { Coefficients }\end{array}$ & \multicolumn{1}{c|}{ S } & \\
\cline { 2 - 4 } & \multicolumn{1}{|c|}{$\mathrm{B}$} & Std. Error & \multicolumn{1}{c|}{ Beta } & & \\
\hline & 45.240 & 49.006 & & .923 & .359 \\
(Constant) & 4.041 & 1.902 & 2.947 & 2.125 & .037 \\
PA & -4.002 & 1.632 & -3.318 & -2.453 & .016 \\
KO & -.735 & 1.365 & -.777 & -.538 & .592 \\
LOC & -.100 & .053 & -3.423 & -1.901 & .061 \\
PA * LOC & .110 & .045 & 4.215 & 2.430 & .017 \\
KO * LOC & &
\end{tabular}

a. Dependent Variable: SA

Sumber : Data Primer Diolah, 2017

Berdasarkan model persamaan regresi dalam penelitian ini maka dapat disimpulkan hasil pada tabel Moderated Regression Analisys sebagai berikut :

$Y=45,240+4,041 X_{1}+-4,002 X_{2}+-0,100 X_{1} \cdot X_{3}+0,110 X_{2} \cdot X_{3}+\mathrm{e}$

Hasil persamaan regresi di atas dapat dijelaskan bahwa :

1) Nilai konstanta (a) sebesar 45,240 yang berarti bahwa apabila tidak ada perubahan pada partisipasi anggaran, komitmen organisasi, dan locus of control maka senjangan anggaran sebesar 45,240.

2) Koefisien partisipasi anggaran sebesar 4,041. Mengindikasikan bahwa setiap peningkatan peran partisipasi anggaran akan meningkatkan terjadinya senjangan anggaran sebesar 4,041.

3) Koefisien komitmen organisasi sebesar $-4,002$ mengindikasikan bahwa setiap peningkatan peran komitmen organsasi akan menurunkan terjadinya senjangan anggaran sebesar $-4,002$.

4) Koefisien interaksi antara partisipasi anggaran dengan locus of control sebesar $-0,100$. Mengindikasikan bahwa setiap penigkatan peran interaksi partisipasi anggaran dengan locus of control akan mengakibatkan penurunan terjadinya senjangan anggaran $-0,100$.

5) Koefisien interaksi komitmen organisasi dengan locus of control sebesar 0,110 . Mengindikasikan bahwa setiap penurunan peran interaksi komitmen organisasi dengan locus of control akan mengakibatkan peningkatan terjadinya senjangan anggaran sebesar 0,110.

\section{Hasil Koefisien Determinasi $\left(\mathbf{R}^{2}\right)$}

Koefisien Determinasi bertujuan untuk mengukur seberapa jauh kemampuan model dalam menerangkan variabel dependen. Nilai koefisien determinasi dapat dilihat pada bagian Adjusted $R$ Square pada tabel di bawah ini. 


\section{Tabel Uji Koefisien Determinasi}

Model Summary

\begin{tabular}{|l|r|r|r|r|}
\hline Model & \multicolumn{1}{|c|}{$\mathrm{R}$} & R Square & \multicolumn{1}{|c|}{$\begin{array}{c}\text { Adjusted } \mathrm{R} \\
\text { Square }\end{array}$} & \multicolumn{2}{|c|}{$\begin{array}{c}\text { Std. Error of the } \\
\text { Estimate }\end{array}$} \\
\hline 1 & $.496^{\mathrm{a}}$ & .246 & .201 & 2.256 \\
\hline
\end{tabular}

a. Predictors: (Constant), KO * LOC, PA, LOC, KO, PA * LOC

Sumber : Data Primer di Olah, 2017

Berdasarkan hasil pengujian pada tabel di atas menunjukkan nilai Adjusted $R$ Square sebesar 0,201. Yang artinya bahwa kontribusi variabel partisipasi anggaran $\left(\mathrm{X}_{1}\right)$, komitmen organisasi $\left(\mathrm{X}_{2}\right)$ dan locus of control $\left(\mathrm{X}_{3}\right)$ dan interaksi antara partisipasi anggaran dengan locus of control serta interaksi antara komitmen organisasi dengan locus of control adalah sebesar 0,201 atau $20,1 \%$. Sedangkan sisanya sebesar $79,9 \%$ dipengaruhi oleh faktor-faktor lain yang tidak diteliti dalam penelitian ini.

\section{Hasil Uji Kelayakan Model (F-test)}

Uji F (uji kelayakan) dilakukan untuk menguji apakah variabel independen secara bersama-sama berpengaruh terhadap variabel dependen atau tidak serta untuk menguji apakah model yang digunakan sudah fix atau belum. Dengan ketentuan bahwa jika signifikan $\rho$ value $\leq \alpha=0,05$ dan $F_{\text {hitung }} \geq F_{\text {tabel, }}$, berarti model tersebut signifikan dan bisa digunakan untuk menguji hipotesis. Hasil uji kelayakan (uji F) dapat dilihat pada tabel di bawah ini :

\section{Tabel Uji Kelayakan Model}

ANOVA $^{a}$

\begin{tabular}{|c|r|r|r|r|r|}
\hline Model & Sum of Squares & \multicolumn{1}{|c|}{ Df } & Mean Square & F & Sig. \\
\hline Regression & 139.407 & 5 & 27.881 & 5.477 & $.000^{\circ}$ \\
Residual & 427.582 & 84 & 5.090 & & \\
Total & 566.989 & 89 & & & \\
\hline
\end{tabular}

a. Dependent Variable: SA

b. Predictors: (Constant), KO * LOC, PA, LOC, KO, PA * LOC

Berdasarkan hasil pengujian diketahui bahwa nilai signifikan $\rho$ value $\leq$ a (alpha) yaitu $0,000 \leq 0,05$, dan $F_{\text {hitung }} \geq F_{\text {tabel }}$ yaitu $5,477 \geq 2,705$. Berarti model yang digunakan dalam penelitian ini sudah layak (fix). Dengan demikian dapat disimpulkan bahwa hipotesis dalam penelitian ini diterima atau Ha diterima dan Ho ditolak.

\section{Hasil Uji Hipotesis (t-test)}

Hasil pengujian secara parsial masing-masing variabel dapat dilihat pada tabel uji Moderated Regression Analysis (MRA). Hasil uji hipotesis dapat diuraikan pada uraian di bawah ini:

1) Pengaruh partisipasi anggaran terhadap senjangan anggaran

Berdasarkan hasil pengujian diketahui bahwa variabel partisipasi anggaran memiliki nilai signifikan $t$ sebesar $0,037 \leq$ taraf signifikansi alpha $=0,05$ dan nilai $t_{\text {hitung }} \geq t_{\text {tabel }}$ yaitu $2,125 \geq 1,987$ dan nilai koefisien $\beta$ sebesar 4,041. Artinya bahwa semakin tinggi partisipasi anggaran pada suatu SKPD pemerintah daerah Kota Tidore Kepulauan akan meningkatkan senjangan anggaran sebesar 4,041. Dari hasil tersebut menunjukkan bahwa Hipotesis pertama $\left(\mathrm{H}_{1}\right)$ yang diajukan pada penelitian 
ini, yaitu partisipasi anggaran berpengaruh positif terhadap senjangan anggaran diterima.

2) Pengaruh komitmen organisasi terhadap senjangan anggaran

Berdasarkan hasil pengujian diketahui bahwa variabel komitmen organisasi memiliki nilai signifikan $t$ sebesar $0,016 \leq$ taraf signifikansi alpha $=0,05$ dan nilai $t_{\text {hitung }} \geq t_{\text {tabel }}$ yaitu $-2,453 \geq 1,987$ dan nilai koefisien $\beta$ sebesar $-4,002$. Yang artinya semakin tinggi komitmen organisasi pada suatu SKPD pemerintah daerah Kota Tidore Kepulauan akan mengakibat penurunan senjangan anggaran sebesar -4,002. Dengan demikian, hipotesis kedua $\left(\mathrm{H}_{2}\right)$ yang ajukan pada penelitian ini adalah komitmen organisasi berpengaruh negatif terhadap senjangan anggaran diterima.

3) Pengaruh partisipasi anggaran terhadap senjangan anggaran yang dimoderasi oleh locus of control

Berdasarkan hasil pengujian diketahui bahwa interaksi antara partisipasi anggaran dengan locus of control memiliki nilai signifikan $t$ sebesar $0,061>$ taraf signifikansi alpha $=0,05$ dan nilai $t_{\text {hitung }}<t_{\text {tabel }}$ yaitu $-1,901<1,987$ dan nilai koefisien $\beta$ sebesar $-0,100$. Dari hasil tersebut menunjukkan bahwa apabila bawahan yang terlibat dalam proses partisipasi anggaran memiliki locus of control yang baik akan menurunkan senjangan anggaran sebesar $-0,100$. Dengan demikian, karena nilai sig $t$ $\geq$ sig a, maka locus of control bukan sebagai variabel moderasi yang memoderasi hubungan antara partisipasi anggaran terhadap senjangan anggaran, sehingga hipotesis ketiga $\left(\mathrm{H}_{3}\right)$ adalah partisipasi anggaran berpengaruh negatif terhadap senjangan anggaran yang dimoderasi oleh locus of control yang diajukan dalam penelitian ini ditolak.

4) Komitmen organisasi berpengaruh terhadap senjangan anggaran yang dimoderasi oleh locus of control

Berdasarkan hasil pengujian diketahui bahwa interaksi antara komitmen organisasi dengan locus of control memiliki nilai signifikan $t$ sebesar $0,017 \leq$ taraf signifikansi alpha $=0,05$ dan nilai $t_{\text {hitung }} \geq \mathrm{t}_{\text {tabel }}$ yaitu $2,430 \geq 1,987$ dan nilai koefisien $\beta$ sebesar 0,110 . Artinya bahwa apabila locus of control yang dimiliki individu pada SKPD pemerintah daerah Kota Tidore Kepulauan tidak baik akan menurunkan komitmen organisasi sehingga komitmen organisasi menjadi rendah, dan jika melibatkan organisasi dengan komitmen yang rendah dalam proses penysunan anggaran maka akan mengakibatkan senjangan anggaran sebesar 0,110. Dengan demikian dilihat dari nilai sig $\mathrm{t} \leq \alpha$, maka hipotesis keempat $\left(\mathrm{H}_{4}\right)$ yang diajukan dalam penelitian ini adalah komitmen organisasi berpengaruh negatif terhadap senjangan anggaran yang dimoderasi oleh locus of control diterima.

\section{PEMBAHASAN}

\section{Pengaruh Partisipasi Anggaran Terhadap Senjangan Anggaran}

Berdasarkan hasil analisis statistik yang dilakukan dalam penelitian ini diketahui bahwa partisipasi anggaran berpengaruh positif dan signifikan terhadap senjangan anggaran. Hal ini berarti bahwa semakin tinggi bawahan yang berpartisipasi dalam proses penyusunan anggaran maka semakin tinggi bawahan berkesempatan untuk melakukan senjangan anggaran. Dengan demikian diketahui bahwa tingkat partisipasi bawahan pada masing-masing 
SKPD di pemerintah daerah Kota Tidore Kepulauan dalam proses penyusunan anggaran semakin tinggi.

Hasil penelitian ini konsisten dengan beberapa penelitian sebelumnya, yaitu penelitian yang dilakukan oleh Tambunan dan Kurniawan, (2014). Hapsari, (2015) juga menunjukkan bahwa penganggaran partisipatif berpengaruh positif terhadap budgetary slack. Desmayani dan Suardhika, (2016) juga menunjukkan hasil penelitian yang sama, yaitu penganggaran partisipatif berpengaruh positif terhadap budgetary slack.

\section{Pengaruh Komitmen Organisasi Terhadap senjangan Anggaran}

Berdasarkan hasil analisis statistik yang dilakukan dalam penelitian ini diketahui bahwa komitmen organisasi berpengaruh negatif terhadap senjangan anggaran. Hal ini yang berarti bahwa organisasi yang memiliki komitmen organisasi tinggi akan mendorong individu yang berada dalam organisasi tersebut bekerja sesuai dengan tujuan-tujuan organisasi yang telah ditetapkan. Hasil ini menunjukkan bahwa pada SKPD pemerintah daerah Kota Tidore Kepulauan memiliki komitmen organisasi tinggi.

Hasil penelitian ini didukung oleh penelitian yang dilakukan Tjahjanti, (2004) dan Nitiari (2014), yang menunjukkan bahwa komitmen organisasi dengan senjangan anggaran memiliki hubungan yang negatif dan signifikan.

\section{Pengaruh Partisipasi Anggaran Terhadap Senjangan Anggaran yang di Moderasi oleh Locus Of Control.}

Berdasarkan hasil analisis statistik yang telah dilakukan dalam penelitian ini diketahui bahwa partisipasi anggaran berpengaruh negatif tidak signifikan terhadap senjangan anggaran yang di moderasi oleh locus of control. Hasil tersebut menunjukkan bahwa jika bawahan yang berpartisipasi dalam proses penyusunan anggaran memiliki locus of control internal yang baik maka bawahan tidak akan melakukan senjangan anggaran atas keterlibatannya dalam proses penyusunan anggaran. Sedangkan bawahan yang memiliki locus of control internal yang tidak baik akan mencari kesempatan untuk melakukan senjangan anggaran.

Hasil penelitian ini tidak sejalan dengan penelitian yang dilakukan Erawati (2015), yang menyatakan bahwa locus of control memoderasi hubungan antara partisipasi anggaran terhadap senjangan anggaran. Sedangkan penelitian yang dilakukan Sosiawan (2014) juga menunjukkan hasil bahwa locus of control berpengaruh signifikan dan negatif terhadap hubungan antara partisipasi anggaran dengan budgetary slack.

\section{Pengaruh komitmen organisasi terhadap senjangan anggaran yang di Moderasi oleh locus of control.}

Berdasarkan hasil analisis statistik yang dilakukan dalam penelitian ini diketahui bahwa locus of control mampu memoderasi hubungan antara komitmen organisasi terhadap senjangan anggaran. Hal ini berarti bahwa individu dengan locus of control yang baik pada suatu organisasi akan membuat organisasi memiliki komitmen yang tinggi. Dengan demikian diketahui bahwa pada SKPD pemerintah daerah Kota Tidore Kepulauan memiliki individu dengan locus of control yang baik sehingga menjadikan organisasi dengan komitmen yang tinggi, dan apabila di ikutsertakan dalam proses partisipasi anggaran maka senjangan anggaran tidak akan terjadi. Hasil ini juga menunjukkan bahwa interaksi antara 
komitmen organisasi dengan locus of control memberikan pengaruh yang positif, yang artinya bahwa apabila individu yang ada pada suatu organisasi memiliki locus of control yang kurang baik akan mengakibatkan komitmen organisasi menjadi rendah.

Menurut Rotter (1966) dalam Hapsari (2010) mengemukakan bahwa terdapat dua sifat dari locus of control yaitu internal locus of control dan eksternal locus of control. Internal locus of control merupakan keyakinan yang terdapat pada tiap individu bahwa mereka memegang kendali terhadap segala sesuatu yang terjadi pada mereka. Eksternal locus of control merupakan tingkat kepercayaan yang ada dalam diri seseorang bahwa segala sesuatu yang terjadi pada mereka dikendalikan oleh kekuatan yang berasal dari luar dirinya seperti peluang, keberuntungan, nasib dan lain-lain.

\section{SIMPULAN DAN SARAN}

Simpulan dari penelitian ini adalah : (1) Partisipasi anggaran berpengaruh positif dan signifikan terhadap senjangan anggaran. (2) Komitmen organisasi berpengaruh negatif dan signifikan terhadap senjangan anggaran.(3) Partisipasi anggaran berpengaruh negatif tidak signifikan terhadap senjangan anggaran yang di moderasi oleh locus of control. Sehingga locus of control bukan sebagai variabel moderasi dalam penelitian ini. (4) Komitmen organisasi berpengaruh positif terhadap senjangan anggaran yang dimoderasi oleh locus of control.

Berdasarkan hasil hasil penelitian yang disimpulkan, maka peneliti menyarankan. 1) Untuk pemerintah daerah kota Tidore Kepulauan, apabila melibatkan organisasi untuk berpartisipasi dalam proses penyusunan anggaran aggaran tetap mempertimbangkan komitmen organisasi yang tinggi, yang dimikili organisasi sehingga tidak terjadi penyalahgunaan anggaran daerah. 2) Bagi peneliti lain yang tertarik untuk melakukan penelitian dengan judul yang sama maka peneliti menyarankan untuk menambahkan dan menggukan variabel lain, karena dari model penelitian yang digunakan hasilnya menunjukan lebih besar pengaruh dari variabel-variabel lain yang tidak diteliti dalam penelitian ini, misalnya kapasitas individu dan ketidakpastian lingkungan. 
Farid Madjodjo. Pengaruh Partispasi Anggaran, Komitmen Organisasi Terhadap Senjangan Anggaran Dengan Locus Of Control Sebagai Variabel Moderasi. Jurnal Equilibrium Vol.3. No.4. Desember 2017

\section{DAFTAR PUSTAKA}

Bambang. 2002. Akuntansi Manajemen Suatu Sudut Pandang. Yogyakarta: BPFE Yogyakarta.

Darlis. 2002. Analisis Pengaruh Komitmen Organisasi dan Ketidakpastian Lingkungan terhadap Hubungan Antara Partisipasi Anggaran Dengan Senjangan Anggaran (Studi Kasus pada Perguruan Tinggi Swasta di DI Yogyakarta). Skripsi Program S-1. Universitas Islam Indonesia.

Dewi. 2008. Pengaruh Budgetary Goal Characteristic terhadap Senjangan Anggaran: Instansi Pemerintah Daerah Kota Padang. Skripsi. Universitas Negeri Padang.

Erawati. 2016. Pengaruh Partisipasi Anggaran Terhadap Kinerja Dan Budgetary Slack Dengan Locus Of Control Sebagai Variabel Pemoderasi.

Erni. 2014. Pengaruh Partisipasi Anggaran terhadap Senjangan Anggaran dengan Penekanan Anggaran dan Komitmen Organisasi Sebagai Variabel Moderasi. E-Jurnal Akuntansi Universitas Ganesha 2 (1).

Erina dan Suartana. 2016. Pengaruh Partisipasi Penganggaran, Penekanan Anggaran, Kapasitas Individu, dan Kejelasan Sasaran Anggaran Pada Senjangan Anggaran. E-Jurnal Akuntansi Universitas Udayana. Vol. 15.2. hal 973-1000.

Falikhatun. 2007. Interaksi Informasi Asimetri, Budaya Organisasi dan Group Cohesiveness Dalam Hubungan Antara Partisipasi Penganggaran dan Budgetary Slack. Symposium Nasional Akuntansi X.

Faujiah. 2007. Pengaruh Partisipasi Penyusunan Anggaran Terhadap Senjangan Anggaran. Jurnal Infestasi. Vol. Nomor 1.

Ghozali. 2006. Aplikasi Analisis Multivariat Dengan Program SPSS. Semarang. Badan Penerbit Universitas Diponegoro.

Hapsari. 2010. Pengaruh Partisipasi Penyusunan Anggaran Terhadap Kinerja Manajerial dengan Komitmen Organisasi dan Locus Of Control Sebagai Variabel Moderating (Studi Kasus Pada PT. Adhi Karya (Persero) Tbk. Devisi Konstruksi I). Skripsi S-1. Universitas Diponegoro

Hansen dan Mowen. 2009. "Akuntansi Manajemen" Edisi 8, Jilid 1, Salemba Empat. Jakarta

Ikhsan dan Ishak. 2005. Akuntansi Keprilakuan. Medan. Salemba Empat

Kartika. 2010. Pengaruh Komitmen Organisasi Dan Ketidakpastian Lingkungan Dalam Hubungan Antara Partisipasi Anggaran Dengan Senjangan Anggaran. Kajian Akuntansi. Vol 2. Hal 39-70. ISSN. 1979-4886.

Latuheru. 2005. Pengaruh Partisipasi Anggaran terhadap Senjangan Anggaran Dengan Komitmen Organisasi sebagai Variabel Moderating. Jurnal Akuntansi \& Keuangan. Vol 7. Hal. 117-130.

Mardiasmo.. 2002. Akuntansi Sektor Publik. Andi Offset. Yogyakarta

Mulyadi. 2001. Akuntansi Manajemen : Konsep Manfaat Dan Rekayasa. Yogyakarta : Salemba Empat. 14

Nordiawan. 2010. Akuntansi Sektor Publik. Jakarta: Salemba Empat.

Nitiari dan Yadnyana. 2014. Pengaruh Partisipasi Penganggaran, Komitmen Organisasi, Dan Ketidakpastian Lingkungan Pada Senjangan Anggaran. EJurnal Akuntansi Universitas Udayana.

Putra dan Priliandani. 2016. Pengaruh Partisipasi Penganggaran Pada Senjangan Anggaran Di Universitas Undayana Dengan Informasi Asimetri Dan Motivasi Sebagai Pemoderasi. E- Jurnal Ekonomi Dan Bisnis Universitas Udayana 
Robbins dan Judge. 2008. Perilaku Organisasi (Organizational Behaviour). Buku 2. Edisi 12. Jakarta. Salemba Empat.

Robbins. 1998. Organization Behavior, Concept,Controvercies, Application, Seventh Edition, Englewood Cliffs.

Suardhika. 2016. Pengaruh Penganggaran Partisipatif, Locus Of Control, Dan Pemberian Reward Terhadap Budgetary Slack. E-Jurnal Akuntansi Universitas Udayana. Volume 16.2.

Sinaga. 2013. Pengaruh Partisipasi Anggaran terhadap Senjangan Anggaran Dengan Locus Of Control dan Budaya Organisasi sebagai Variabel Pemoderasi. (Studi Empiris pada SKPD Kota Pematang Siantar).

Soejoso. 2004. Pengaruh Anggaran Partisipasi dan Komitmen Organisasi terhadap Kinerja Manajerial : Ketidakpastian Lingkungan Sebagai Pemoderasi. Tesis Pada Program Pascasarjana Universitas Diponegoro.

Sosiawan. 2014. Pengaruh Locus Of Control Terhadap Hubungan Antara Partisipasi Anggaran Dengan Budgetary Slack. Jurnal Akuntansi UMRAH.

Suliyanto. 2011. Ekonomitrika Terapan: Teori dan Aplikasi dengan SPSS. Yogyakarta. ANDI

Tambunan dan Kurniawan. 2014. Pengaruh partisipasi penganggaran terhadap senjangan anggaran dengan komitmen organisasi dan ketidakpastian lingkungan sebagai variabel moderating.

Tjahjanti. 2004. Pengaruh Partisipasi Penyusunan Anggaran, Komitmen Organisasi, Keterlibatan Kerja, dan Ketidakpastian Lingkungan Terhadap Senjangan Anggaran. Tesis Universitas Diponegoro. 